\title{
ADDITIONAL EDUCATIONAL PROCESS FOR HIGH SCHOOL STUDENTS
}

\author{
Saule Ibragimova \\ PhD Student, Nukus state pedagogical institute named after Ajiniyaz, Nukus, Uzbekistan
}

Article DOI: https://doi.org/10.36713/epra7849

DOI No: 10.36713/epra7849

\begin{abstract}
The article deals with theoretical insights into the meaningful use of extracurricular leisure time by high school students in secondary educational institutions. The article also describes the main goals and objectives of additional education for school pupils. The article discusses how students can spend their free time through physical education and sports, maintaining and improving their health, as well as meaningful extracurricular activities.

KEY WORDS: additional education, leisure, physical education, culture, pedagogy, initiative.
\end{abstract}

\section{INTRODUCTION}

In Uzbekistan, thirty percent of the country's population is between 14 and 30 years old. They have a wide range of conditions for education and professional development. At the same time, it is important to organize meaningful leisure time for young people. The more spiritually mature young people are, the stronger their immunity to various vices will be. It is known that the head of our state put forward 5 important initiatives to organize the work in the social, spiritual and educational spheres on the basis of the new system. They are the following:

- The first initiative is to increase the interest and talent of young people in music, painting, literature, theater and other arts;

- The second initiative is aimed at creating the necessary conditions for young people to exercise and show their abilities in sports;

- The third initiative is aimed at promoting the effective use of computer technology and the Internet among the population and youth;

- The fourth initiative is aimed at raising the morale of young people and organizing systematic work to promote reading among them;

- The fifth initiative is the employment of women.

In a short time great work has been done. For example, 300,000 copies of fiction were delivered to district and city libraries of Syrdarya region. Music and art schools were equipped with musical instruments and sports facilities. According to the first initiative, today only 130,000 boys and girls are enrolled in more than 800 cultural centers, 312 music and art schools in the country, most of which have textbooks and a set of notes. , musical instruments, furniture and equipment were not adequately provided. The head of country instructed to study the material and technical base of local cultural centers, music and art schools and the state of their use, and to improve their activities. The Ministry of Culture and the Ministry of Public Education, together with the authorities, have been tasked to establish an additional 1,500 clubs in district (city) cultural centers and secondary schools based on the interests of young people. There was a need to establish amateur art groups, youth theater studios and "Youth Clubs" in cultural centers, involving talented young people and local sponsors [6].

Thus, the state youth policy in Uzbekistan is being pursued with a clear goal, step by step, based on comprehensive measures. In this regard, Shavkat Mirziyoyev put forward 5 important initiatives to systematically make efforts in the social, spiritual and educational spheres on the education of youth in the history of Uzbekistan. This noble idea of the head of state was met with great interest by the people of Uzbekistan, especially the youth, and in a short period of time spread throughout the country. Under these five initiatives which will be widely implemented in the future, the material and technical base and use of cultural centers, music and art schools in the regions have dramatically improved, and due to the interest of young people, an additional 1,500 clubs have been established. Furthermore, in the cultural centers of the most remote villages, there are amateur art groups, youth theater studios and "Youth clubs". In addition, more than 12,000 sports 
facilities across the country will be provided with maximum coverage of young people, and all secondary schools will be fully equipped with sports equipment. At the same time, small gyms and artificial turf fields will be built from lightweight sandwich panels in remote areas. The number of sports schools for children and teenagers will be increased.

Digital technology training centers have been established in all regions on the basis of international best practices in protecting young people from harmful attacks on the Internet and training them in the effective use of information technology. These facilities provide free e-commerce and programming training, innovative business skills in information technology, and support for startup projects. An action plan to provide computer classrooms in all schools with modern technology and high-speed Internet are being developed and implemented in stages. The new computer game centers will be equipped with tests, quizzes, development strategies and other useful programs aimed at expanding the knowledge and outlook of the younger generation [7]. Moreover, in order to strengthen the reading skills of young people, the new initiative has delivered at least 1 million copies of books to the Republic of Karakalpakstan and all regions. At the same time, one sample bookstore will be established in each city and district center, mobile book pavilions will be set up, and library services will be provided to the population of villages and villages through "Bibliobus".

\section{LITERATURE REVIEW}

Pedagogy of additional education, being an independent direction in science and practice, is only fragmentarily represented in programs and textbooks of higher professional education in general pedagogy, although its potential, a variety of research topics can claim to be an independent course. The purpose of additional education for children is to create organizational and pedagogical conditions for professional, social, personal self-determination, selfrealization and development of pupils. The main goal of additional education for pupils is concretized by the following tasks:

- creating conditions for the manifestation and development of various individual abilities of pupils; - education and practical training of a free, independent, creative, professionally oriented citizen, capable of cooperation in the interests of a person, society, state;

- development and implementation of the intellectual potential, creative abilities of the child's personality, the formation of interest and motivation for creative and research activities in a specific field of science, technology, culture, production;
- disclosure and implementation of the teacher's creative potential.

Researchers of the problems of additional education from different positions approach the definition of the functions of additional education [5]. Let's dwell on them in more detail. Asmolov notes the function of continuity, since additional education passes through all stages of education: preschool, school, primary vocational and higher. In this case, it is secondary in relation to school, but it becomes the basis on which a developing variable education is built, the purpose of which is the development of personality motivation. The educational and informational function presupposes not only the transfer of knowledge about the phenomena of the world to the child, but also his knowledge of the meaning of this or that reality, the essence and nature of objects, phenomena of the surrounding world. The value function contributes to the formation of the child's value orientations. The personality-forming function is focused on the development of the child's personality. Psychological and therapeutic function is a comfortable microclimate, creative activities, friendly relations between pupils and teachers, favorably affecting the mental state of the child. Ensuring the employment of children in their free time at school reduces the field of deviant behavior and can be considered as a means of preventing young people's crime [1].

\section{METHODOLOGY}

The educational process is understood as a system for constructing the interaction of teaching and learning, education and self-education, which ensures the development of the individual as an individual. This system largely depends on the specifics of institutions, leading pedagogical technologies used by them. Over the entire history of the existence of the system of out-of-school education, and later of additional education, historically, several types of institutions of additional education for children have developed. The determination of types of institutions is based on the priority of goals, direction, profile, features of the organization and provision of the educational process, educational results, the system of their accounting and control. The types of institutions of additional education are represented by centers, palaces, houses, clubs, stations, schools, young people's studios, parks, museums (pupil's creativity, literature, art), children's health camps [2].

Physical education and sport as a means of preserving and improving the health of pupils.

The concept of "culture" can be defined as the degree of disclosure of the potential of an individual in various fields of activity. Culture is represented in the results of human material and 
spiritual activity; he learns the culture, fixed in spiritual and material values, acts in the social environment as a bearer of cultural values, creates new values necessary for the development of the culture of subsequent generations. Physical culture is an organic part of universal human culture, its special independent area. At the same time, this is a specific process and result of human activity, a means and method of physical improvement of a person. Physical culture affects the vital aspects of the individual, received in the form of inclinations, which are transmitted genetically and develop in the process of life under the influence of upbringing, activities and the environment. Physical culture satisfies social needs for communication, play, entertainment, in some forms of personal selfexpression through socially active useful activities. At its core, physical culture has a purposeful motor activity in the form of physical exercises, which allow to effectively form necessary skills and abilities, physical abilities, to optimize the state of health and working capacity.

Thus, physical culture should be considered as a special kind of cultural activity, the results of which are useful for society and the individual. In social life in the system of education, upbringing, in the field of work organization, everyday life, healthy recreation, physical culture manifests its educational, health-improving, economic and general cultural significance, contributes to the emergence of such a social trend as physical culture movement, such as joint activities of people to use, disseminate and enhance the values of physical culture.

\section{RESULTS AND DISCUSSION}

Sport is part of physical culture. In sport, a person seeks to expand the boundaries of his capabilities, this is a huge world of emotions generated by successes and failures, the most popular spectacle, an effective means of education and selfeducation of a person, there is a complex process of interhuman relations in it. Sport is actually a competitive activity and special preparation for it. A student lives by certain rules and norms of behavior. It clearly shows the desire for victory, the achievement of high results, requiring the mobilization of the physical, mental and moral qualities of a person. Therefore, they often talk about the sports nature of people who successfully manifest themselves in competitions. Satisfying many human needs, playing sports becomes a physical and spiritual necessity. Physical culture of a person manifests itself in three main directions. Firstly, it determines the ability for self-development, reflects the orientation of the individual "towards himself", which is due to his social, spiritual experience, and ensures his desire for creative "self-construction", self-improvement. Secondly, physical culture is the basis of an amateur, proactive self-expression of a future specialist, the manifestation of creativity in the use of physical culture means aimed at the subject and the process of his professional work. Thirdly, it reflects creativity of the individual, aimed at relations arising in the process of physical culture, sports, social and professional activities. The richer and wider the circle of personal ties in this activity, the richer the space of its subjective manifestations becomes. Interest in physical culture and interest in sports are different stages in the development of one interest. An interest in physical education can develop into an interest in sports. An active interest is an interest in exercising. Passive interest in physical culture is a spectacular, informational and cognitive interest that is not associated with active exercises. Passive interest can develop into active interest, or it can remain so throughout a person's life [4].

Thus, interest in physical culture is an integral result of complex processes in the motivational sphere of schoolchildren. However, the motivation for physical education has always been brought up and is being brought up always, at any lesson, but the effect in the formation of interest is still insignificant: only a few out of hundreds of schoolchildren are engaged in physical education on their own. The fact is that there is motivation in relation to the student internal and external. Interest arises only on the basis of intrinsic motivation. It endures great physical and neuro-emotional stress with interest, at the request of the student himself. It is called "flow sensation" in foreign psychology. In this case, the student performs tasks, exercises with enthusiasm, as if pushed by the force of some invisible stream.

\section{CONCLUSION}

Thus, additional education is carried out in various types of educational institutions. The determination of the types of institutions is based on the priority of goals, the number of directions and profiles and their priority, the peculiarities of the organization and provision of the educational process; the level of educational results, as well as the system of their accounting and control. The most common types of institutions for additional education for children are centers, palaces, houses, clubs, stations, schools, children's studios, parks, museums (pupil's creativity, literature, art). Extracurricular activities are an integral part of the teaching and educational activities of the school, which are organized after school, with children's selfmanagement, or with the active support and tactical guidance of teachers, class and counselors [3]. There is a close connection between educational work in the classroom and extracurricular activities: learning 
activities, the development of students' interest in knowledge, contribute to the development of extracurricular activities, and in addition, allows students to apply their knowledge in practice, expanding and deepening this knowledge, helping to increase students' achievement and interest in learning.

\section{REFERENCES}

1. Andreev, V.I. Pedagogy: textbook. course for creative self-development / V.I. Andreev. $2^{\text {nd }}$ edition. Kazan: Center for Innovative Technologies, 2000.

2. Funikova, N.I. An integrated approach as a factor in the organization of additional education for children: author. Dissertation cand. ped. sciences / N.I. Funikova. Chelyabinsk, 1998.

3. Kairova, I.A. Pedagogical encyclopedia. [Text]. / ed. I.A. Kairova F.N. Petrov. M., 1964.

4. Kuldashova, N.V. Navigator of extracurricular activities. [Text]. Volgograd: Teacher. 141.

5. Samoshkina, T.G. The individuality of the individual as a means of development of the theme week [Text] // Pedagogical skills: IV internship materials. Scientific work. Conf. (Moscow, February 2014). M. Buki-Vedi, 2014. 133 - 136.

6. https://buxdu.uz/index.php/uz/faoliyat/madani y-ma-rifiy/ma-naviy-ma-rifiy-tadbirlar/24415-ta-muhim-tashabbus

7. https://strategy.uz/index.php?news $=615$ \&lan $g=u z$ 